\title{
PATIENTERNA VID SINNESSJUKHUSET FÖR FÅNGAR
}

\author{
Av Matti I. Joukamaa, Vilho J. Mattila, Raimo K. R. Salokangas, \\ Vilho I. Jäppinen, Lauri Salmi och Hannu Holm
}

\section{Inledning}

De psykiskt sjuka brottslingarna utgör ur både teoretisk och praktisk synvinkel en betydelsefull grupp vid gränsen mellan psykiatri och kriminologi. Inom den psykiatriska litteraturen torde rätt allmänt råda den uppfattningen, att brottslighet och psykisk stördhet mer än vanligt har samband med varandra (t. ex. Kinberg 1930, Johansson 1974). Enligt de psykoanalytiskt orienterade forskarna kan brottet betraktas som ett adaptationsalternativ för svår psykisk stördhet (t. ex. Halleck 1967, Tuovinen 1973). Mer än försök att skapa en enhetlig teori om psykiska störningar och brottslighet har man i litteraturen framlagt enstaka utredningar om sambanden mellan olika typer av brott och olika slag av psykiska störningar.

Det måhända klaraste sambandet har konstaterats mellan å ena sidan schizofrenin och å andra sidan våldsbrottsligheten och mordbränderna (Kaila 1941, Virkkunen 1974). Psykopatin har ofta sammankopplats med brottsligheten (t. ex. Achté m. fl. 1973). Bl. a. Kaila (1950), Ahto (1951) och Guze m. fl. (1969 och 1974) har studerat sambandet mellan psykopati och brottslighet. Inom kriminologin begränsas dock bruket av psykopatibegreppet p.g.a. dess obestämdhet; i definitionerna råkar man lätt in i cirkelbevis (Clinard 1957). Simons och Cornier (1969) fäste uppmärksamhet vid att kroniska psykoser oftare förekommer bland fångar än bland befolkningen i medeltal och antog att psykopatin, som hade samband med återfallsbrottsligheten, senare ofta förvandlades till kronisk psykos.

Också mellan alkoholismen och brottsligheten har man ansett att det råder ett samband, speciellt beträffande ungdomsbrottslingarna (Dahlberg 1943). Guze m. fl. (1962 och 1964) samt Gloniger och Guze (1970) kom vid systematiska undersökningar till ett sådant resultat, att alkoholism och beroende av läkemedel både hos manliga och kvinnliga brottslingar skulle utgöra de huvudsakliga psykiatriska symtomen, som vid sidan av sociopatin förekommer hos fullvuxna fångar. I de senaste undersökningarna har man dock ifrågasatt det direkta sambandet mellan alkoholismen (eller beroendet av läkemedel) och brottsligheten (t. ex. Hybinette m. fl. 1972, Lindelius och Salum 1973, Gibbens 1972).

I Finland har man traditionellt gjort kriminologiska undersökningar i rätt stor utsträckning. Arbeten som behandlar psykiskt störda fångar har dock publicerats rätt sparsamt och de flesta av dessa undersökningar är 
föråldrade. Mot denna bakgrund ansåg man det nödvändigt att utreda de bakgrundsfaktorer, som är förknippade med brottslighet och psykisk stördhet, samt fångarnas utgallring till de psykiatriska mottagningarna och sinnessjukhuset för fångar. Undersökningen gjordes vid fängelserna i Ăbo

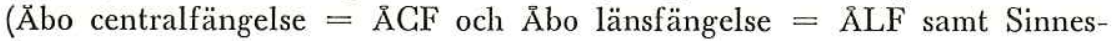
sjukhuset för fångar $=\mathrm{SSF})$. Om undersökningsserien har tidigare skrivits tre rapporter (Jäppinen m. fl. 1978, Mattila m. fl. 1978 och Salokangas m. fl. 1978) och två sammanfattningar (Salokangas m. fl. 1977 och Mattila m. fl. 1979). Detta referat gäller uttryckligen patienterna vid sinnessjukhuset för fångar. (En grundligare framställning har publicerats på finska Mattila m. fl. 1978). I redogörelsen framlägges uppgifter om patienternas socioekonomiska bakgrund, deras psykiatriska anamnes samt brottslighet. Vi undersöker vilka skillnader man kan observera jämfört med andra »vanliga « fångar. Vi utreder dessutom patienternas psykiatriska rön och undersöker huruvida patienterna, som tillhör olika diagnos och symtomklasser, skiljer sig från varandra beträffande bakgrundsvariablerna.

\section{Undersökningsförfarandet}

Undersökningen gjordes vid SSF i Åbo. SSF är ett mentalsjukhus, som underlyder fångvårdsavdelningen vid Justitieministeriet och har 40 patientplatser. Vid tidpunkten för undersökningen var SSF i praktiken det enda psykiatriska sjukhuset för manliga fångar i Finland. Där fanns då en överläkare på deltid och en avdelningsläkare på heltid, vilka gjorde de psykiatriska intervjuer, som hörde till undersökningen, och de var samtidigt ansvariga för patienternas vård. En sjukskötare specialiserad i psykiatri samlade med hjälp av intervjuer under läkarnas ledning ihop uppgifterna om patienternas bakgrundsfaktorer. Undersökningsmaterialet bestod av de finska patienter, som för första gången intogs till SSF under tidsperioden 1. 6.-30. 9. 1974. Sålunda utgjorde populationen 106 fångar. Som jämförelsegrupp använde man i denna undersökning en population bestående av finska manliga fångar, som under samma tid intogs till fängelserna i Åbo, 108 fångar från ÅLF och 87 fångar från ÅCF. Hur denna population uppstod och likaledes hela undersökningsmetoden har i detalj redogjorts för på annat håll (Jäppinen m. fl. 1978). Vid granskningen av resultaten jämför man patienterna vid SSF $\left(A_{s}\right)$ med kontrollgruppen (I) och skilt för sig de patienter, som kommit till SSF från fängelserna i Åbo $\left(A_{a}\right)$, och de, som kommit från andra fängelser i Finland $\left(A_{a}\right)$. Detta beror på åbofångarnas stora andel samt dessutom på det faktum att de kommer från samma grundpopulation som kontrollgruppens fångar.

\section{Materialets representativitet}

De patienter, som intogs till SSF under undersökningsperioden, utgjorde $33 \%$ av patientantalet under hela året. Andelen har varit ungefär lika 
stor under motsvarande tidpunkt också andra år. Av patienterna kom 46\% från centralfängelserna, $39 \%$ från länsfängelserna, $12 \%$ från reservfängelserna och $3 \%$ från ungdomsfängelset. I detta hänseende avvek inte undersökningsmaterialet väsentligt från det normala patientmaterialet vid SSF. Däremot var fångarna, som kommit från fängelserna i Åbo, överrepresenterade. I undersökningspopulationen hade varannan patient $(49 \%)$ kommit till SSF från fängelserna i Ảbo, då motsvarande siffra för hela år 1974 var endast $38 \%$.

\section{Undersökningens resultat}

\subsection{Patienternas bakgrund}

\subsection{1. Ålder och familjeförhållanden}

Populationernas åldersfördelning framgår ur tabell 1. Fångarna vid SSF var yngre än fångarna i jämförelsegruppen. I båda populationerna var fångarna tydligt yngre än åldersfördelningen i den finska 15 år fyllda manliga befolkningen (FOS 1973). Patienternas åldersfördelning vid SSF motsvarar ganska exakt åldersfördelningen för alla finska fångar år 1974 (Fångarnas åldersfördelning för år 1974 baserar sig på Justitieministeriets utredning »Statistiska uppgifter om fångar 1975«). Däremot motsvarade åldersstrukturen för de fångar, som från Åbo kommit till SSF, åldersstrukturen i kontrollgruppen.

Tabell 1. Åldersfördelningen (\%)

\begin{tabular}{lcccc}
\hline & $\mathrm{I}$ & $\mathrm{A}_{\mathrm{s}}$ & $\mathrm{A}_{\mathrm{a}}$ & $\mathrm{A}_{\mathrm{a}}$ \\
Älder (år) & $\mathrm{N}=195$ & $\mathrm{~N}=106$ & $\mathrm{~N}=54$ & $\mathrm{~N}=52$ \\
\hline-17 & 1 & 2 & - & 4 \\
$18-20$ & 7 & 8 & 2 & 15 \\
$21-24$ & 18 & 22 & 11 & 33 \\
$25-29$ & 26 & 29 & 37 & 21 \\
$30-39$ & 22 & 18 & 18 & 19 \\
$40-49$ & 22 & 18 & 28 & 8 \\
$50-$ & 4 & 2 & 4 & -
\end{tabular}

Största delen eller cirka $2 / 3$ av både patienterna och kontrollgruppen var ogifta. Även i detta hänseende avvek båda populationerna klart från den manliga befolkningen i Finland (FOS 1973). I kontrollgruppen fanns det nästan dubbelt så många gifta än i patientgruppen (andelarna var $12 \%$ och $7 \%$ ). Karakteristiskt för gruppen, som intagits till SSF från fängelserna i Ăbo, var den stora andelen frånskilda: mera än en tredjedel av samtliga. Största delen av patienterna hade bott ensamma innan de kommit till 
fängelset. Här fanns en klar skillnad jämfört med kontrollgruppen; av patienterna vid SSF bodde endast $11 \%$ i äktenskap eller samvetsäktenskap, av kontrollgruppen $31 \%$.

\subsubsection{Bakgrundsuppgifter om hemmet}

Beträffande hemmets bakgrund var populationerna i flera avseenden likadana. Hemmets splittring mättes med frågor rörande föräldrarnas skilsmässa, eventuell styvfar eller styvmor samt huruvida de undersökta i sin barndom bott hos sina föräldrar eller på olika anstalter. Med avseende på dessa variabler kunde man i fördelningen inte konstatera märkbara skillnader mellan grupperna. $73 \%$ av kontrollgruppens fångar och $70 \%$ av patienterna hade tillbringat hela sin barndom hemma. Procentandelarna för dem, som i sin barndom bott utanför hemmet, framgår ur tabell 2. Patienterna vid SSF hade varit placerade på betydligt flera ställen än de övriga fångarna, dvs. en och samma patient torde $\mathrm{i}$ sin barndom ofta ha varit placerad på flera än ett ställe.

Tabell 2. Andelen, som i barndomen bodde utanför föräldrahemmet $(\%)$

\begin{tabular}{llc}
\hline Placering & $\mathrm{I}$ & $\mathrm{A}_{\mathrm{s}}$ \\
\hline Barnhem & 5 & 8 \\
Skolhem & 7 & 12 \\
Fosterföräldrar & 5 & 10 \\
Mor- eller farföräldrar & 2 & 4 \\
På annat håll & 5 & 1
\end{tabular}

Beträffande släktningarnas psykiatriska vård konstaterades skillnader endast då det gällde »de övriga släktingarna« (= den undersöktas syskon, föräldrarnas syskon och mor- och farföräldrar). I patientgruppen var andelen $20 \%$ och i kontrollgruppen $6 \%$. Mödrarnas och fädernas psykiatriska vård (mödrarna: I $7 \% \mathrm{~A}_{\mathrm{s}} 10 \%$, fäderna: $\mathrm{I} 4 \% \mathrm{~A}_{\mathrm{s}} 6 \%$ ) motsvarade siffrorna i normalbefolkningen.

\subsubsection{Utbildning och yrke}

För $13 \%$ av patienterna vid SSF begränsade sig grundutbildningen till avbruten folkskolgång, då motsvarande tal för jämförelsegruppen var endast

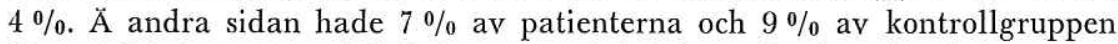
fått utbildning utöver folkskolexamen. Också beträffande yrkesskolning var grupperna likadana, cirka $4 \%$ hade ingen annan utbildning utöver yrkeskurser. Egentlig yrkesutbildning hade $13 \%$ av patienterna och $16 \%$ av kontrollgruppen. 
Då man jämförde de undersöktas socialgrupptillhörighet använde man sig av en treklassig socialgruppering, som utarbetats av Rauhala (Rauhala 1966). I SSF-populationen fanns något flera, som hörde till de lägsta socialgrupperna, än i jämförelsegruppen. Också mellan undergrupperna vid SSF fanns en klar skillnad: $71 \%$ av dem, som kommit från andra orter än Åbo, hörde till de lägsta grupperna, då motsvarande tal för åbofångarna var endast $44 \%$. Skillnaden utjämnas i någon mån då man beaktar att åbofångarna oftare helt och hållet saknade yrke.

\subsubsection{Arbete}

Innan de kommit till fängelset hade $2 / 3$ av kontrollgruppens fångar och endast $1 / 3$ av fångarna vid SSF varit $i$ arbete. Studier och värnplikt har här jämställts med arbete. Såsom ur tabell 3 framgår förklaras skillnaden mellan de arbetandes antal i första hand genom arbetslösheten. I patientgruppen fanns det dessutom flera sådana, som varit på andra anstalter, varit sjuklediga eller pensionerade. Denna grupp var speciellt stor bland de patienter, som intagits till SSF från fängelserna i Åbo. Då man granskar de arbetslösas andel, som dock var stor också i kontrollgruppen, bör man komma ihåg, att den nu rådande depressionen inte ännu hade börjat i Finland vid tidpunkten för undersökningen.

Tabell 3. De undersöktas arbetssituation före intagningen till fängelset $(\%)$

\begin{tabular}{llll}
\hline & $\mathrm{I}$ & $\mathrm{A}_{\mathrm{s}}$ & $\mathrm{A}_{\mathrm{a}}$ \\
\hline
\end{tabular}

Arbetade, studerade eller

avtjänade $\sin$ värnplikt

Arbetslös

Sjukledig, på anstalt eller pensionerad

Uppgifter saknas

$\begin{array}{rrr}67 & 32 & 30 \\ 18 & 42 & 39 \\ 13 & 21 & 26 \\ 2 & 5 & 5\end{array}$

Under de senaste fem åren $\mathrm{i}$ frihet hade $64 \%$ av patienterna vid SSF varit i förvärvsarbete. I jämförelsegruppen var siffran $82 \%$. Denna skillnad förorsakas av gruppen, som intagits till SSF från fängelserna i Åbo. Av dem hade endast $48 \%$ varit i förvärvsarbete, då däremot $81 \%$ av dem, som kommit från andra orter, hade arbetat. Av de patienter vid SSF, som haft arbete, hade $59 \%$ varit arbetslösa under de senaste fem åren $\mathrm{i}$ frihet, i kontrollgruppen endast $8 \%$. Endast för $11 \%$ av patienterna hade det sista arbetsförhållandet varat över ett år, i jämförelsegruppen var motsvarande tal $18 \%$. Då de kommit till fängelset hade endast $27 \%$ av de förvärvsarbetande patienterna varit i kontinuerligt arbete då siffran för jämförelsegruppen var $54 \%$. Ovanstående resultat talar klart för en sämre arbetsanamnes för patienterna vid SSF. Däremot är resultaten inte entydiga 
mellan de olika grupperna vid SSF. Ảbofångarna förefaller att ha en bättre yrkesstatus men en sämre arbetsanamnes än de, som kommit från andra orter.

\subsubsection{Tidigare psykiatrisk vård}

De undersöktas tidigare psykiatriska vård under vistelse $\mathrm{i}$ frihet har framställts i tabell 4. Over hälften av patienterna vid SSF hade vårdats på mentalsjukhus, i jämförelsegruppen $17 \%$. Patienterna, som intagits till SSF

Tabell 4. Tidigare psykiatrisk vård $(\%)$

\begin{tabular}{lrrr}
\hline & $\mathrm{I}$ & $\mathrm{A}_{\mathrm{s}}$ & $\mathrm{A}_{\mathrm{a}}$ \\
\hline Ingen vård & 70 & 40 & 41 \\
Endast öppen vård & 12 & 6 & 11 \\
En gång på mentalsjukhus & 7 & 7 & 5 \\
Flera gånger » & 10 & 45 & 41 \\
Uppgifter saknas & 1 & 2 & 2
\end{tabular}

från Åbo, hade färre vårdperioder än de övriga patienterna. Denna skillnad utjämnas dock, när man räknar med också den öppna vården. $16 \%$ av kontrollgruppen hade vistats på alkoholistanstalt, siffran för SSF-patienterna var $17 \%$. $11 \%$ av kontrollgruppen hade genomgått sinnesundersökning och $26 \%$ av patienterna. Skilt från övriga vårdperioder granskades tidigare vistelser på SSF. Så mycket som $15 \%$ av jämförelsegruppen hade tidigare vistats på SSF. Siffran förefaller hög, i synnerhet då $15 \%$ av jämförelsegruppens fångar för första gången var i fängelse. Ännu mera överraskande verkar det då endast ungefär var femte patient vid SSF var där för första gången.

\subsubsection{Tidigare brottslighet}

I båda populationerna var hälften tukthusfångar, en fjärdedel rannsakningsfångar och en fjärdedel vanliga fångar (Tabell 5). För första gången i fängelse var $15 \%$ av kontrollmaterialet, $21 \%$ av patienterna och endast

Tabell 5. Typ av fångenskap $(\%)$

\begin{tabular}{lrrr}
\hline & $\mathrm{I}$ & $\mathrm{A}_{\mathrm{s}}$ & $\mathrm{A}_{\mathrm{a}}$ \\
\hline Rannsakning p. g. a. lösdriveri & 1 & - & - \\
Bötesfånge & 2 & - & - \\
Rannsakningsfånge & 30 & 26 & 24 \\
Vanlig fånge & 20 & 22 & 7 \\
Tukthusfånge & 47 & 53 & 69
\end{tabular}


$7 \%$ av de SSF-patienter, som intagits från Åbo. $\AA$ andra sidan hade $53 \%$ av kontrollgruppen varit i fängelse flera än 5 gånger, av SSF-gruppen $40 \%$ och av åbofångarna vid SSF $66 \%$. I medeltal hade patienterna vid SSF färre frihetsstraff än kontrollgruppen, å andra sidan hade patienterna, som intagits från fängelserna i Åbo, det största antalet frihetsstraff.

Patienterna vid SSF hade begått flera våldsbrott än kontrollgruppen, som i sin tur hade flera narkotika- och alkoholbrott (Tabell 6). Egendomsbrottens andel var nästan lika stor i båda grupperna, däremot hade åbopatienterna vid SSF inte så ofta som de övriga gjort sig skyldiga till våldsbrott.

Tabell 6. Typen av brott $(\%)$

\begin{tabular}{lrrr}
\hline & $\mathrm{I}$ & $\mathrm{A}_{\mathrm{s}}$ & $\mathrm{A}_{\mathrm{a}}$ \\
\hline Våldsbrott & 17 & 29 & 19 \\
Egendomsbrott & 59 & 61 & 74 \\
Alkohol- el. narkotikabrott & 15 & 7 & 6 \\
Annat brott & 7 & 3 & 2 \\
Uppgifter saknas & 1 & - & -
\end{tabular}

\subsection{Patienterna vid Sinnessjukhuset för fångar}

4.2.1. Intagningen till Sinnessjukhuset för fångar

Vid undersökningstidpunkten intogs patienterna till SSF, liksom också till de övriga mentalsjukhusen i Finland, med s.k. MII-förfarande (= frivillig vårdansökan) och M III-förfarande (= av läkare skriven remiss för vård mot patientens vilja). Största delen $(63 \%)$ intogs med en M-II : a, $33 \%$ med en M-III : a och $4 \%$ utan remiss. Från fängelserna i Åbo intogs $24 \%$ med M III-förfarandet och från de övriga fängelserna $42 \%$. Våldsbrottslingarna och de, som satt i fängelse för första gången, intogs oftare än de övriga med M III-förfarandet.

Snabbheten vid intagningen till SSF mättes i dagar räknat från det datum remissen skrevs till intagningsdagen. Det är kanske överraskande att det inte förekom skillnader i intagningssnabbheten mellan fångarna från Åbo och fångarna från de övriga fängelserna.

\subsubsection{Psykiatrisk bedömning vid intagningen till SSF}

Läkarna vid Sinnessjukhuset för fångar intervjuade patienterna i allmänhet samma dag de anlände till sjukhuset eller därpå följande dag. Vid intervjun bedömde man orsaken till intagningen, symtomens svårighetsgrad och suicidrisken samt ställde en preliminär diagnos.

Enligt läkarna, som tog emot patienterna, led största delen av patienterna tydligt av en psykisk sjukdom eller symtom därav $(77 \%) .8 \%$ antogs ha 
kommit till SSF på grund av anpassningssvårigheter till fängelselivet och $6 \%$ p. g. a. missbruk av berusningsmedel. Däremot föreföll $8 \%$ att ha andra orsaker till intagningen, såsom t. ex. begäran om läkarutlåtande eller svårigheter utanför fängelset. Dessa orsaker förekom tydligt i större utsträckning hos åbofångarna. $27 \%$ av fångarna från Åbo intogs på grund av annan orsak än sjukdomssymtom, då motsvarande tal för fångarna från övriga orter var bara $15 \%$.

Vid intagningen bedömde man skilt för varje patient $\mathrm{i}$ vilken mån hans symtom inverkade på hans möjligheter att komma till rätta i fängelset. $4 \%$ var symtomfria, av lindriga symtom (vilka inte antogs inverka väsentligt på möjligheterna att klara sig i fängelset) led 21\%. Måttliga symtom (som inverkade menligt på möjligheterna att klara sig normalt) konstaterades hos $43 \%$ och svåra symtom (svårt eller omöjligt att komma till rätta $\mathrm{i}$ fängelset) hade $31 \%$. Inga skillnader konstaterades mellan de olika fängelserna. Av bakgrundsvariablerna var det endast brottets art, som hade betydelse för symtomen: hos våldsbrottslingarna förekom det oftare än hos de övriga måttliga eller svåra symtom.

Som lindrigt suicidala symtom klassificerades hotelser om att skada sig själv eller göra självmord samt yppande av självmordstankar. Svåra symtom ansåg man det vara fråga om då patienten skadade sig själv samt annars visade uppenbar suicidalitet. Svåra suicidala symtom konstaterades hos $18 \%$ och lindriga symtom hos $15 \%$. Mellan de olika fängelserna kunde inte skillnader av betydelse konstateras. Med stigande ålder och större antal fängelsevistelser föreföll suicidaliteten att avta. I de högre socialgrupperna föreföll det att förekomma mindre suicidalitet än i de lägre. Hos våldsbrottslingarna förekom det mera suicidala symtom än hos de övriga.

Enligt den preliminära diagnos, som ställdes vid intagningsintervjun, led var tredje $(34 \%)$ av störningar av psykotisk karaktär. Ungefär lika många led av neurotiska symtom $(34 \%$ ). $8 \%$ missbrukade berusningsmedel eller narkotika och $12 \%$ led av karaktärsavvikelser. $5 \%$ av patienterna var psykiskt friska enligt läkarnas bedömning. Av patienterna från Ảbo var endast $32 \%$ psykotiska. Bland dem fanns däremot flera med rusmedelseller narkotikaproblem och till och med $7 \%$ ansågs vara friska.

\subsubsection{Diagnoserna}

Då patienterna utskrevs från SSF ställdes en huvuddiagnos och vid behov andra diagnoser med hjälp av den internationella sjukdomsnomenklaturen (Rev. 8). I tabell 7 har man ställt upp de med sjukdomsnomenklaturen överensstämmande huvuddiagnosklasserna enligt ursprungsfängelse. Som huvuddiagnos förekom hos $26 \%$ av alla patienter en psykotisk störning. Hos $31 \%$ av dem, som kommit från andra orter, var huvuddiagnosen psykos och samma gällde för endast $20 \%$ av åbofångarna. En klar skillnad fanns 
Tabell 7. Huvuddiagnos (Internationella sjukdomsnomenklaturen) enligt ursprungsfängelse $(\%)$

\begin{tabular}{lccc}
\hline & $\begin{array}{c}\mathrm{A}_{\mathrm{s}} \\
\mathrm{N}=106\end{array}$ & $\begin{array}{c}\mathrm{A}_{\mathrm{a}} \\
\mathrm{N}=54\end{array}$ & $\begin{array}{c}\mathrm{A}_{\mathrm{a}} \\
\mathrm{N}=52\end{array}$ \\
\hline Schizofreni & 13 & 9 & 17 \\
Annan sinnessjukdom & 13 & 11 & 14 \\
Neuros & 15 & 17 & 14 \\
Karaktäropati (Pers. pathol.) & 14 & 11 & 17 \\
Alkoholism eller narkomani & 11 & 11 & 12 \\
Annan psyk. störning eller reaktion & 28 & 33 & 6 \\
Org. sjukdom eller skada & 5 & 4 & - \\
Uppgifter saknas & 2 & 4 & 20
\end{tabular}

också vad beträffar de övriga psykiska symtomen. Det verkar som om fångarna från Åbo i högre grad än de övriga skulle ha haft icke-psykotiska fängelsereaktioner.

I tabell 8 har man för de olika patientgrupperna angivit de totala procenttalen för psykoser, karaktäropatier och missbrukare av olika ämnen. Siffrorna har erhållits genom sammanslagning av huvud- och bidiagnoserna. Det totala procenttalet för psykoserna (30) var praktiskt taget exakt det samma som år 1971 (Betänkande för arbetsgrupp vid Justitieministeriet 1973). Psykospatienter hade i större utsträckning intagits från fängelserna utanför Åbo. Beträffande karaktäropatierna och alkoholismen och narkomanin ser det däremot ut som om förhållandet vore det motsatta.

Tabcll 8. Diagnossammanställningarna enligt ursprungsfängelse ( $\%$ )

\begin{tabular}{lccc}
\hline & $\begin{array}{c}\mathrm{A}_{\mathrm{s}} \\
\mathrm{N}=106\end{array}$ & $\begin{array}{c}\mathrm{A}_{\mathrm{a}} \\
\mathrm{N}=54\end{array}$ & $\begin{array}{c}\mathrm{A}_{\mathrm{a}} \\
\mathrm{N}=52\end{array}$ \\
\hline Psykos & 30 & 26 & 35 \\
Karaktäropati (Pers. pathol.) & 34 & 37 & 31 \\
Alkoholism eller narkomani & 45 & 48 & 42
\end{tabular}

Åldern hade inget klart entydigt samband med förekomsten av störningar. Det totala antalet psykoser såg ut att stiga något med stigande ålder. Också karaktäropatier och addiktionsproblem förekom mest i den äldsta åldersgruppen (över 29 år), men också i den yngsta åldersgruppen förekom dessa störningar i högre grad än medeltalet.

Som huvuddiagnos förekom inte schizofreni, karaktäropati eller addiktionsproblem hos en enda av de gifta. Dock var det bara 7 personer, som 
Tabell 9. De sammanställda diagnoserna enligt civilstånd $(\%)$

\begin{tabular}{lcccc}
\hline & $\begin{array}{c}\text { Ogifta } \\
\mathrm{N}=72\end{array}$ & $\begin{array}{c}\text { Gifta } \\
\mathrm{N}=7\end{array}$ & $\begin{array}{c}\text { Frånskilda } \\
\mathrm{N}=26\end{array}$ & $\begin{array}{c}\text { Summa } \\
\mathrm{N}=105\end{array}$ \\
\hline Psykos & 29 & 29 & 35 & 30 \\
Karaktäropati & 40 & 14 & 23 & 34 \\
Alkoholism eller narkomani & 50 & 29 & 38 & 46
\end{tabular}

var gifta. Då man beaktade huvuddiagnoserna och bidiagnoserna sammanlagt, förekom psykoser mest hos de frånskilda (Tabell 9). Karaktäropatier och addiktionsproblem förekom mest hos de ogifta, men minst hos de gifta. På det hela taget verkade det som om de, som var gifta, inte hade störningar i lika hög grad som de övriga.

Sambandet mellan antalet fängelsevistelser och diagnoserna framgår ur tabell 10. För varannan av de fångar, som satt i fängelse för första gången, blev diagnosen psykos. Minsta antalet psykoser förekom hos dem, som satt inne för 6.-8:nde gången. Då antalet fängelsevistelser blev större än så, såg det ut som om antalet psykoser åter skulle stiga. Man bör dock observera att det $\mathrm{i}$ materialet fanns endast 13, som hade suttit i fängelse flera än 3 gånger. Antalet karaktäropatier steg också med stigande antal fängelsevistelser, likaså antalet missbrukare.

Tabell 10. Diagnossammanställningarna i relation till antal fängelsevistelser (\%)

\begin{tabular}{lcccc}
\hline & $\begin{array}{c}1 \text { :a vist. } \\
\mathrm{N}=22\end{array}$ & $\begin{array}{c}2 .-5 \text { :te v. } \\
\mathrm{N}=41\end{array}$ & $\begin{array}{c}6 .-8: \text { :nde v. } \\
\mathrm{N}=30\end{array}$ & $\begin{array}{c}\text { Over 8 vist. } \\
\mathrm{N}=13\end{array}$ \\
\hline Psykos & 50 & 27 & 20 & 31 \\
Karaktäropati & 18 & 32 & 43 & 46 \\
Alkoh. el. nark. & 36 & 46 & 43 & 62
\end{tabular}

\subsubsection{Patienternas vård}

Läkemedlen intog fortfarande en rätt central plats inom vården. I enlighet med vad, som är brukligt i fängelserna, strävade man till att undvika läkemedel ur bentsodiatsepingruppen. I praktiken bestod medicineringen av neuroleptiska och tricykliska antidepressiva preparat. Som neuroleptiska preparat klassificerade man också sömnmedel med fenotiazinbas. Största delen av patienterna $(66 \%$ ) fick enbart neuroleptisk medicinering, $20 \%$ fick en kombination av neuroleptiska och antidepressiva läkemedel och $5 \%$ endast antidepressiv medicinering. Helt utan medicinering var $8 \%$ av patienterna. 
20 av undersökningsmaterialets patienter fick individuell terapi, 10 fick gruppterapi, 16 sysselsättningsterapi, 9 konstterapi, 9 musikterapi, samt 21 socioterapi. Vid tidpunkten för undersökningen fanns vid SSF 1 läkare anställd på heltid och en på deltid, likaså en psykolog på heltid och en på deltid. Dessutom fanns vid SSF en sysselsättnings- och en konstterapeut. Båda läkar- och psykologtjänsterna var tillfälligt besatta. Dessutom inföll undersökningstidpunkten på sommaren. Det finns skäl att anta, att ovanstående resultat inte ger en representativ bild av läget under normalare förhållanden. Vårdtiderna på SSF blev längre för de fångar, som intagits från övriga orter, än för åbofångarna. T. o. m. $52 \%$ av dem, som intagits från andra orter, stannade på SSF över en månad, då motsvarande tal för åbofångarna var endast $30 \%$. Skillnaden beror närmast på det, att patienterna från de övriga fängelserna var verkligen svårt psykotiska. $\AA$ andra sidan bör man observera, att möjligheterna att få vård på en psykiatrisk mottagning var mindre i de övriga fängelserna än i fängelserna i Åbo.

För våldsbrottslingarna var vårdtiderna längre än för de fångar, som gjort egendomsbrott, vilket stämde överens med tidigare observationer. Av de förstnämnda vistades $9 \%$ högst 2 veckor på SSF och $25 \%$ av de sistnämnda. $\AA$ andra sidan översteg vårdtiden en månad för $58 \%$ av våldsbrottslingarna och $37 \%$ av fångarna, som gjort egendomsbrott. För alkohol- och narkotikabrottslingarna var den vanligaste vårdtiden 15-30 dygn.

För dem, som intagits för vård p. g. a. psykos eller speciellt schizofreni, blev vårdtiden naturligtvis lång; i allmänhet erhöll de vård från en till tre månader. De klart kortaste vårdtiderna hade patienterna med karaktäropatidiagnos; av dem vårdades ungefär varannan kortare tid än två veckor. Vanligaste vårdtiden för patienterna med addiktionsproblem var 15-30 dygn. Detta var typiskt också för gruppen med »annan psykisk sjukdom eller symtom«.

\section{Diskussion}

Populationen, som bestod av patienter vid SSF, var representativ vad beträffar ursprungsfängelsets typ. Nya patienter intogs till SSF ungefär i samma takt som annars också sommartid. Patienterna från fängelserna i Åbo var märkbart överrepresenterade i populationen. Detta berodde antagligen delvis på att undersökningen utfördes på sommaren. P. g. a. sommarledigheterna fanns det mindre utbud av hälsovårdsservice $\mathrm{i}$ de mindre fängelserna och likaså remitterades patienter till SSF i mindre skala än på vintern. Också fångforslingen fungerade sämre under semestertiden. Vid fängelserna i Åbo däremot kunde hela sommaren åtminstone en del av mottagningarna utnyttjas. Ovverrepresentationen av fångar från Åbo kunde också delvis bero på själva undersökningen: De, som utförde undersökningen, samarbetade rätt intensivt då de utförde olika vårduppgifter vid fängelserna i Åbo och SSF. 
Patienterna vid SSF var något yngre än kontrollgruppens fångar. Båda grupperna var klart yngre än hela Finlands 15 år-fyllda befolkning. Åldersfördelningen i SSF-populationen motsvarade åldersfördelningen för samtliga fångar; patienterna, som intagits från Åbo, var ungefär lika gamla som fångarna i jämförelsegruppen. Man kan konstatera, att patientmaterialet vid SSF inte var utgallrat vad åldern beträffar.

I båda grupperna fanns det frånskilda och ogifta i betydligt högre grad än i normalbefolkningen. I flera tidigare undersökningar har man konstaterat att patienterna vid mentalsjukhus oftare än genomsnittsbefolkningen är ogifta eller frånskilda eller hör till de lägre socialgrupperna (t. ex. Stenbäck och Achté 1964, Olkinuora 1967, Salokangas 1977). Också »de vanliga fångarna « i population I kan i detta hänseende förliknas vid de mentalt sjuka patienterna, som beskrivs i ovannämnda undersökningar. Bland SSFpatienterna fanns ännu flera ogifta och frånskilda än i jämförelsegruppen och av dem hade en större del levt ensamma före fängelseintagningen. Man kan säga, att bland fångarna, som också annars har en sämre förmåga att knyta kontakter till andra människor, accentueras svårigheterna ytterligare hos de psykiskt störda.

Beträffande hembakgrunden var populationerna i många avseenden homogena och avvek inte mycket från normalbefolkningen. Hemmets splittring föreföll inte enligt denna undersökning att förebåda brottslighet och psykisk stördhet. T. ex. Ahto har i sina undersökningar om tvångsinrättningsfångar funnit ett större antal splittrade hem (Ahto 1951). Anmärkningsvärt är dock att en stor del av de undersökta åtminstone en del av sin barndom bott utanför föräldrahemmet. Speciellt stor var denna andel i gruppen, som hade intagits till SSF från fängelserna i Åbo. Dessutom hade de av SSF-patienterna, som bodde utanför hemmet i sin barndom, ofta haft flera än en placeringsort.

Både grund- och yrkesskolningen var sämre för SSF-patienterna än för kontrollgruppen. Det är möjligt att anlagen att bli psykiskt störd redan i skolåldern har inverkat negativt på skolframgången.

Socialgruppen för patienterna vid SSF konstaterades vara något lägre än jämförelsegruppens. En del av skillnaden kan förklaras genom att en mindre andel var utan yrke i patientgruppen, och att skolningsnivån var lägre $\mathrm{i}$ patientgruppen. De patienter, som intagits till SSF från fängelserna i Ảbo, hade en högre social status än de övriga patienterna. Delvis torde detta bero på att de var äldre och delvis på att de fått yrkesutbildning i fängelset.

De mest betydande skillnaderna mellan de undersökta grupperna uppstod i variablerna, som mätte förvärvsarbete. Förmågan, kanske också viljan, till regelbundet arbete var klart sämre i patientgruppen än i kontrollgruppen. Patientgruppen blir lätt arbetslös, anställningarna är kortvariga och oregelbundna, arbetsanamnesen är inte kontinuerlig. Dessutom var ungefär var femte ur patientgruppen sjukledig, pensionerad eller intagen 
på annan anstalt före intagningen till fängelset. De sistnämndas andel var särskilt stor i gruppen, som intagits till SSF från fängelserna i Åbo.

Båda grupperna hade tidigare fått psykiatrisk vård i betydligt större omfattning än normalbefolkningen. Skillnaden mellan grupperna var dock tydlig. Av patienterna vid SSF hade ungefär varannan åtminstone en gång tidigare fått vård på mentalsjukhus. Den s.k. avbrytningsvården för alkoholister räknades också med. Alkoholismen torde dock inte förklara skillnaderna mellan grupperna, emedan det $\mathrm{i}$ båda grupperna förekom vård på alkoholistanstalt i ungefär lika hög grad.

Ungefär $80 \%$ av patienterna vid SSF hade tidigare vårdats på SSF. Denna siffra är verkligen hög då man ytterligare beaktar det faktum, att cirka en femtedel av populationen för första gången satt i fängelse. På basen av detta ser det ut som om prognosen för patienterna vid SSF inte skulle vara särskilt bra.

Man har redan konstaterat att fångarna från Åbo är överrepresenterade i populationen. Trots att de var överrepresenterade intogs inte fångarna från Åbo för vård snabbare än de övriga fångarna, fastän fångforslingen som kännt fungerar långsamt. På grund av att symtomen hos fångarna från Ảbo i allmänhet var lindrigare än hos de övriga, var deras behov av vård sällan akut. Fångarna från Ảbo var inte heller i lika hög grad störda som de övriga patienterna. Bland fångarna från Åbo fanns det färre psykoser och flera icke-psykotiska fängelsereaktioner samt alkohol- och narkotikaproblem och karaktäropatier än bland de övriga.

För endast $14 \%$ ställdes vid undersökningstidpunkten karaktäropati som huvuddiagnos. Speciellt beträffande karaktäropatierna ser diagnoserna ut att variera beroende på olika åskådningssätt hos de olika läkarna vid SSF. Ar 1971 hade $40 \%$ karaktäropati som huvuddiagnos. Neuros som huvuddiagnos förekom då i $14 \%$ av fallen, i denna undersökning $15 \%$. Kriterierna för alkoholism var kanhända strängare än vanligt i denna undersökning. År 1971 förekom alkoholismen som en diagnos i $60 \%$ av fallen och nu endast i 45\% (uppgifterna för år 1971: Arbetsgruppens vid Justitieministeriet betänkande 1973).

Då man undersökte förekomsten av psykoser enligt ålder, fann man det minsta antalet i gruppen 21-29 år och det största antalet i gruppen över 29 år. Fastän det inte fanns något samband mellan åldern och symtomen som helhet, konstaterade man dock suicidala tendenser mest i den yngsta åldersgruppen. Hos de yngsta förekom också mest karaktäropatier. Detta kunde bero på att de befann sig i ett prepsykotiskt stadium, som kanske senare manifesterades som psykos. Denna tanke har framkastats av Simons och Cormier (1969). Antalet fängelsevistelser föreföll att korrelera rätt tydligt med variablerna, som beskriver diagnoser och symtom. Psykoser förekom mest hos dem, som satt i fängelse för första gången, men förekom i rätt hög grad också hos de svårare återfallsförbrytarna. Av de psykotiska 
fångar, som satt i fängelse för första gången, blev en del kanske senare genom sinnesundersökningar kriminalpatienter och kom så bort från fängelserna, och på detta sätt minskas antalet psykoser bland de fångar, som har flera fängelsevistelser bakom sig. Man konstaterade att karaktäropatiernas och addiktionsproblemens antal stadigt ökade med stigande antal fängelsevistelser. De svåraste symtomen fanns allmänt taget hos fångar, som endast få gånger vistats i fängelse.

Också beträffande brottstypen var resultaten rätt entydiga. Psykoser fanns mest hos våldsbrottslingarna och de hade också genomgående svårare symtom än de övriga.

\section{Sammanfattning}

I undersökningen jämför man en population bestående av patienter, som intagits på SSF, med en annan population, som under samma tidsperiod kommit till ÅCF och ÅLF. I båda grupperna gjordes en utförlig strukturerad anamnestisk intervju och i SSF-populationen utfördes dessutom en semistrukturerad psykiatrisk intervju.

Patienterna avvek inte nämnvärt från jämförelsegruppen beträffande civilstånd och social status. Resultatet torde få sin förklaring däri att fångarnas fördelning enligt civilstånd och sociala ställning var klart lägre än hela befolkningens. Fångarnas fördelning enligt civilstånd motsvarade situationen för mentalsjukhuskroniker. Vad beträffar hembakgrunden blev resultaten obetydliga. En väsentlig skillnad fann man endast däri att patientgruppens släktingar oftare än de övriga hade fått psykiatrisk vård.

Patientgruppen och jämförelsematerialet skilde sig klart från varandra endast beträffande arbetsanamnesen och den tidigare psykiatriska vården. Patienterna hade haft en påtagligt sämre framgång i arbetslivet än fångarna i allmänhet och de hade också oftare än de övriga fångarna fått psykiatrisk vård både i det civila och vid SSF.

Största delen av patienterna kom till SSF på eget initiativ rekommenderade av fängelsemyndigheterna. Ungefär en fjärdedel av patienterna var psykotiska. Patienterna, som intagits från fängelserna i Åbo, var störda i mindre grad än de övriga patienterna. Psykoser förekom mest i den äldsta åldersgruppen. Likaså förekom psykoser mest hos dem, som satt i fängelse för första gången men i hög grad också hos återfallsbrottslingarna. Ofta föreföll psykosen att ha samband med våldsbrottsligheten. Karaktäropatiernas och addiktionsproblemens antal konstaterades stiga med stigande antal fängelsevistelser. Hos de gifta förekom samtliga psykiska störningar i mindre skala än hos de övriga. Vårdtiden korrelerade tydligt med störningens svårighetsgrad. Förutom läkemedel fick en anmärkningsvärd del av patienterna psykoterapi i olika former. 


\section{LITTERATUR}

Achté, K., Y. O. Alanen \& P. Tienari: Psykiatria. WSOY, Porvoo 1971.

Adler, G. \& L. N. Shapiro: Psychotherapy with prisoners. Current Psychiat. Therapies $1969: 9: 99-105$.

Clinard, M. B.: Sociology of deviant behavior. Rinehart Co., New York 1957.

Cloninger, C. R. \& S. B. Guze: Psychiatric illness and female criminality: The role of sociopathy and hysteria in the antisocial woman. Amer. J. Psychiat. 1970. 127: 303-311.

Dahlberg, G.: Risken att dömas för svårare brott. Nord Tidskr. f. Strafferet 1943: 145-201.

Gibbens, T. G. N.: Drink, drugs and delinquency. Med. Sci. Law 1972.

Goldmeier, J., E. G. Patterson \& R. H. Sauer: Community mental health and the mentally ill offender. Maryland State Med. J. $1972: 21: 56-59$.

Greenland, G.: The three special hospitals in England and patients with dangerous, violent or criminal propensities. Med. Sci. Law $1970: 10: 93-103$.

Guze, S. B.: Psychiatric illness and crime with particular reference to alcoholism: A study of 223 criminals. J. Nerv. Ment. Dis. 1962, 134: 512-521.

Guze, S. B., D. W. Goodwin \& J. B. Crane: Griminality and psychiatric disorders. Arch. Gen. Psychiat. 1969. 20: 583-591.

Guze, S. B., R. A. Woodruff \& P. J. Clayton: Psychiatric disorders and criminality. JAMA 1974. 6: 641-642.

Halleck, S. L.: Psychiatry and dilemmas of crime. Harper \& Row, New York 1967.

Hybbinette, B., R. Lindelius \& I. Salum: Social investigation. Salum, I. (toim.): Delirium tremens and certain other acute sequels of alcohol abuse. Acta Psychiat. Scand. 1972: Suppl. 255: 76-85.

Johanson, E.: Background and development of youth prison inmates. Scand. J. Soc. Med. 1974: Suppl. 9.

Jäppinen, V. I., V. J. Mattila, M. I. Joukamaa, R. K. R. Salokangas, L. Salmi \& H. Holm: Turun vankilatutkimus I. Tutkimusasetelma ja vankien tausta. Kansanterveysticteen julkaisuja 1978: M 42.

Kaila, M.: Mielisairauksien ja sielullisten vajavuustilojen yleisyydestä rikoksiin syyllistyneiden joukossa. Eripainos Lakimieslehdestä No 4, WSOY, Porvoo 1941.

Kaila, M.: Nuorisorikollisuus. WSOY, Porvoo 1950.

Kempe, G. T.: Aftercare for mentally abnormal offenders in the Netherlands. Int. Psychiat. Clinics 1968: 5: 152-169.

Kinberg, O.: Aktuella kriminalitetsproblem i psykologisk belysning, Natur och Kultur, Stockholm 1930.

Kriminalvård i anstalt. Betänkande avgivet av kommittén för anstaltsbehandling inom kriminalvården. Statens offentliga utredningar 1971: 74, Justitiedepartementet, Stockholm 1971.

Lindelius, R. \& I. Salum: Alcoholism and criminality. Acta Psychiat. Scand. 1973. 49: 306-314. 
Mattila, V., M. I. Joukamaa, H. Holm, R. K. R. Salokangas, V. I. Jäppinen ja L. Salmi: Turun vankilatutkimus III. Vangit Vankimielisairaalassa. Kansanterveystieteen julkaisuja 1978: M 44.

Mattila, V. J., R. K. R. Salokangas, V. I. Jäppinen, M. I. Joukamaa, L. Salmi ja H. Holm: Brottsligheten och fångarnas psykosociala bakgrund.

Oikeusministeriön asettaman työryhmän mietintö. Vankien psykiatrisen hoidon järjestäminen. Helsinki 1973.

Olkinuora, M.: Psykiatriseen sairaalahoitoon tulleiden tamperelaisten yhteiskunnallinen asema. Duodecim 1967: 83: 1002-1010.

Owens, D.: A psychiatric treatment program for convicts. Curr. Psychiat. Ther. 1970: 10: 179-181.

Rauhala, U.: Suomalaisen yhteiskunnan sosiaalinen kerrostuneisuus, WSOY, Porvoo 1966.

Salokangas, R. K. R.: Skitsofreniaan sairastuneiden psykososiaalinen kehitys. Kansaneläkelaitoksen julkaisuja AL:7, Turku 1977.

Salokangas, R. K. R., V. I. Jäppinen, L. Salmi, V. J. Mattila, M. I. Joukamaa \& H. Holm: Fångarna på psykiatrisk mottagning. Nordisk Tidsskrift for Kriminalvidenskab $1977: 64: 192-208$.

Salokangas, R. K. R., V. I. Jäppinen, L. Salmi, V. J. Mattila, M. I. Joukamaa \& H. Holm: Turun vankilatutkimus II. Vangit psykiatrisilla vastaanotoilla. Kansanterveystieteen julkaisuja 1978: M 43.

Simons, S. P. \& B. M. Cormier: Delinquent acting out and ego structure. Laval Méd. 1969: 40: 933-935.

Snyderman, G. S.: Rehabilitating the ex-offender, ex-addict. Int. J. Addict. 1974: 9: $701-717$.

Stenbäck, A. \& K. Achté: An epidemiological study of psychiatric morbidity in Helsinki. Acta Psychiat. Scand. 1964: Suppl. 180: 287-307.

Suomen virallinen tilasto VI C. 104, Väestölaskenta 1970, osa I. Tilastokeskus, Helsinki 1973.

Tauti- ja kuolinsyyluokitus, Valtion painatuskeskus, Helsinki 1969.

Tilastotietoja vangeista. Oikeusministeriö, Vankeinhoito-osasto. Sarja D, selvite no $1,1975$.

Tuovinen, M.: Crime as an Attempt at Intrapsychic Adaptation. Acta Univ. Ouluensis, Series D Medica no 2 Psychiatr. no 1, Oulu 1973 a.

Tuovinen, M.: Kriminaalipotilaat. Duodecim 1973 b: 89: 950—954.

Virkkunen, M.: Täyttä ymmärrystä vailla olevien sosiaalipsykiatrisesta tilasta. Sos. Aikakauskirja $1973: 67: 682-686$.

Virkkunen, M.: On Arson Commited by Schizophrenics. Acta Psychiat. Scand. 1974: 50: 2: $152-160$.

Virkkunen, M.: Kriminaalipotilaiden hoito tehokkaammaksi. Suomen lääkärilehti 1974: 29: 1597-.

Whitehead, J. A. ja M. Ahmad: Chance, mental illness, and crime. Lancet 1970: 1: 135-137. 